\title{
The design of the CNC milling machine
}

\author{
Piotr Boral ${ }^{1, *}$ \\ ${ }^{1}$ Czestochowa University of Technology, Institute of Mechanical Technologies, Al. Armii Krajowej \\ 21, 42-201 Czestochowa, Poland
}

\begin{abstract}
CNC machine tools are currently predominating in the machine-building industry. Generally, these machine tools are equipped with control systems supplied by the world's leading manufacturers, such as Siemens, Fanuc or HeidenHein, and are very expensive. In parallel, many cheap amateur and semi-professional $\mathrm{CNC}$ machine tool solutions are being developed. Below, a CNC milling machine of welded construction is described, which is intended to be, at the same time, a test stand. The design of the milling machine is based on steel closed sections of a large cross-section and a big wall thickness. This has allowed a rigid frame structure to be obtained. To obtain high displacement accuracy, high-accuracy profiled rail slideways have been used, along which prestressed linear ball bearings move. The machine tool has been furnished with a fourth numerically controlled axis, which is demountable.
\end{abstract}

Keywords: machine tools, mach3, welded frame

\section{Introduction}

Aside from professional CNC machine tools used in many branches of industry $[1,2]$, the market of amateur solutions of such machine tools is intensively developing. For amateur $\mathrm{CNC}$ machine tools, their main distinguishing feature is a low manufacturing cost.

Most often, these are 3-axis machine tools of a bolted construction based on aluminium section bars (Figure 1), or even wooden section bars, sometimes of large overall dimensions. It is, therefore, hard to expect rigidity and accuracy from such solutions. A control system commonly used in such machine tools is Mach3 which, in spite of its high capabilities, is very cheap.

Shown below is the authors' design of a 4-axis welded-construction CNC milling machine with enhanced rigidity and machining accuracy, which is intended to be, at the same time, a test stand [4].

The worm described in the article was made on this milling machine [5]. The machine was successfully used to shape the helical surface of the worm with an arbitrary axial profile and the required accuracy of mating area with the worm wheel [6, 7], and spur gears with tooth line modification [8] machined by Step by Step method.

\footnotetext{
* Corresponding author: piotrek@itm.pcz.czest.pl

Reviewers: Maciej Berdychowski, Krzysztof Talaśka
} 


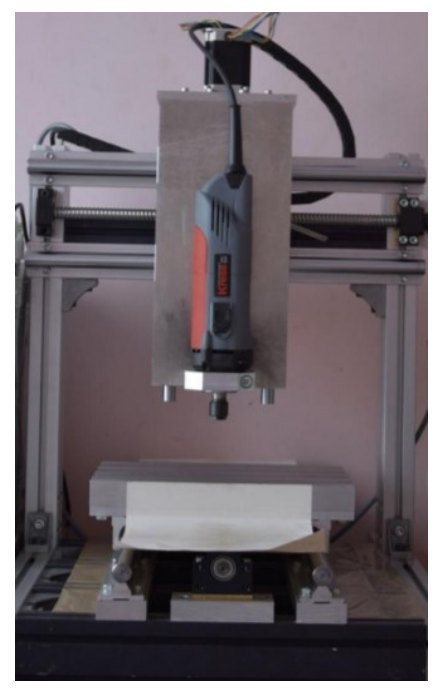

Fig. 1. A section bar-construction $\mathrm{CNC}$ milling machine [3]

\section{The control system}

In view of its low cost, the Mach3 program has been used for control, which is the most common CNC machine control software program, both for commercial and noncommercial applications $[9,10]$. It controls the operation of stepper motors or servo-drives. Thanks to its capability to simulate a PLC controller and ModBus communication, Mach3 offers the possibility of transforming a PC into the controller of practically any machine. The program controls the machine operation based on G-codes (up to 10,000,000 lines), which can be prepared from vector files using, e.g., the LazyCam program. The program can control any set of a controller and a stepper motor. Also, any mechanical solution of drive transmission can be used (e.g. screws, toothed bars or toothed belts) - the program is able to define the work parameters of each axis separately. There is the capability to control up to 6 axis and to use macros written in VBscript. The program's window offers the preview of the tool path and the ongoing monitoring of machining parameters, such as feed rate or spindle rotational speed.

Machine tools of this type commonly utilize the SSK-MB1/2 controller - Figure 2 [11]. The SSK-MB2 main board is designed for connecting up to 4 stepper motor (servo) controllers to a PC furnished with the LPT parallel port. All devices (controllers, limit switches, the spindle) are hooked up independently to respective port pins. There may also be controller versions that communicate with the computer using the USB port, Ethernet, or based on a PLC controller. 


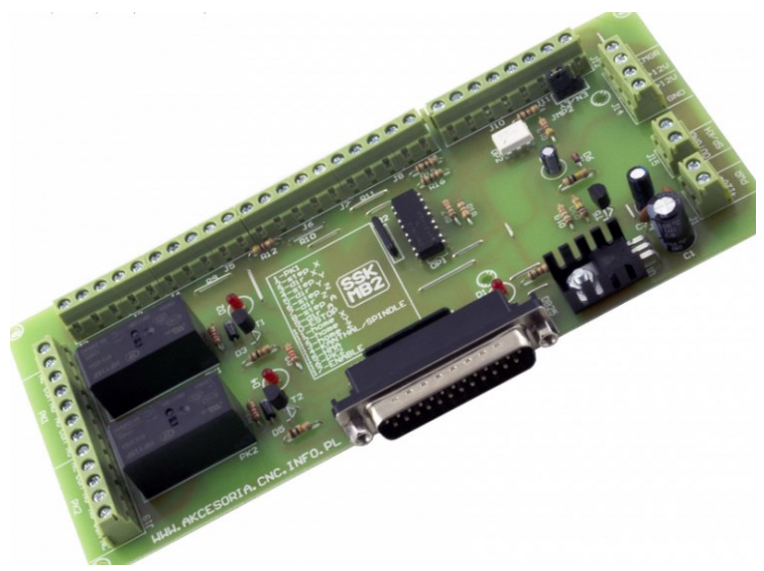

Fig. 2. The CNC SSK MB2 control main board [11]

In the machine tool under discussion, the more expensive SmoothStepper controller is implemented [12], which is a 6-axis motion controller that communicates with the computer via the Ethernet port - Figure 3.

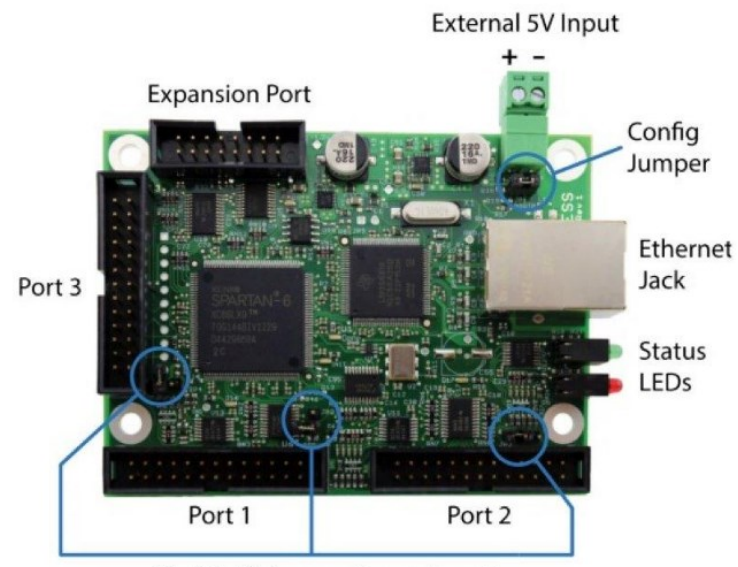

Pin 265 V Jumper for each port

Fig. 3. The Ethernet-based Smoothstepper [12]

Based on received control signals, Mach 3 generates a high-quality high-frequency rectangular waveform for the stepper motors and the servo-drives. By cooperating with Mach3, a controller connected to the computer's Ethernet port can substitute for even three LPT ports of the computer. This allows computers that are not furnished with the LPT port as standard to control the machine's operation using the Mach3 program.

For the configuration and control of the controller's operation, two windows $[9,13]$ are used, which can be found in the Plugin Control main menu of Mach3. 


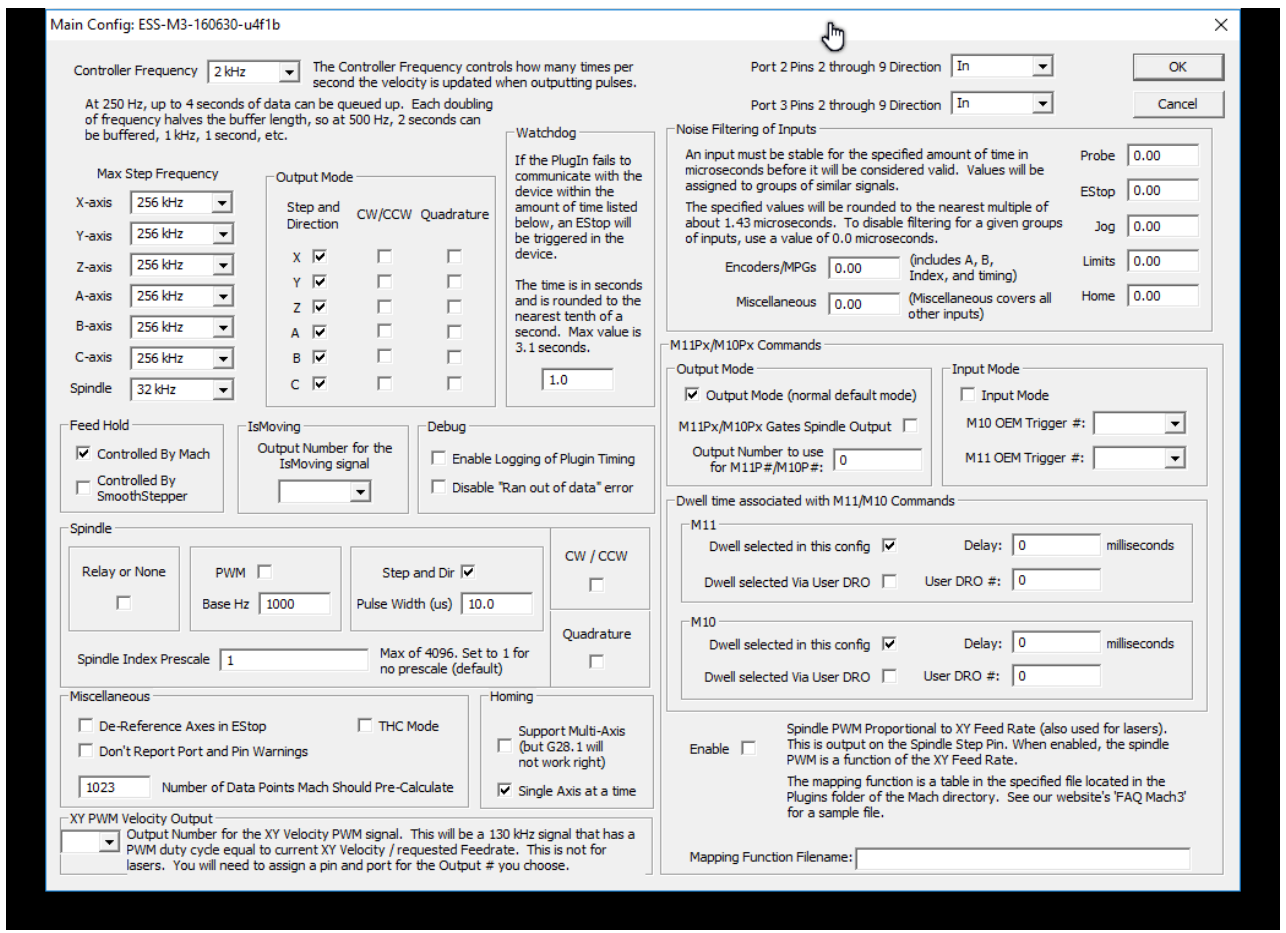

Fig. 4. The window for the configuration of the computer's communication with Mach3

The first of them, Figure 4, enables the configuration of the communication of the SmoothStepper controller with the Mach3 program. This includes the capability to define:

- the frequency, at which the updating of transmitted data (Controller Frequency) is to take place, that is how many times per second the motor speed should be refreshed during the controller's operation. The higher the refresh rate, the "smother" the motor run should be. However, increasing this value will also bring about adverse effects, such as a reduction of the data buffer (each time the frequency is doubled, the buffer capacity will decrease by half). A higher refresh rate cause also a greater load of the Ethernet connection between the controller and the computer.

- the maximum frequency of control pulses for individual axes (Max Step Frequency). Set the nearest frequency higher than the frequency required for a given axis (depending on the expected speed and the number of motor steps, while allowing for the controller's microstep, or the number of servo-drive encoder pulses). If in doubt as to which frequency to select, $4 \mathrm{MHz}$ can be set. The motor run might not be "smooth" at that case, but the controller's counters should not become overfilled.

- the spindle control method (Spindle). One of the three control modes can be selected: On/Off, PWM signal, and the step and the direction.

The orientation of pins from 2 to 9 of Port 2 can also be defined (thus obtaining more inputs). PlugIn offers also the capability to define a kind of a software filter for individual input signals (Noise Filtering ). The purpose of this is to eliminate the noise.

If changes in the setting of maximum frequencies for individual axes have been made, then readjust the motors (Motor Tuning) and restart the program for the new settings to take effect. 


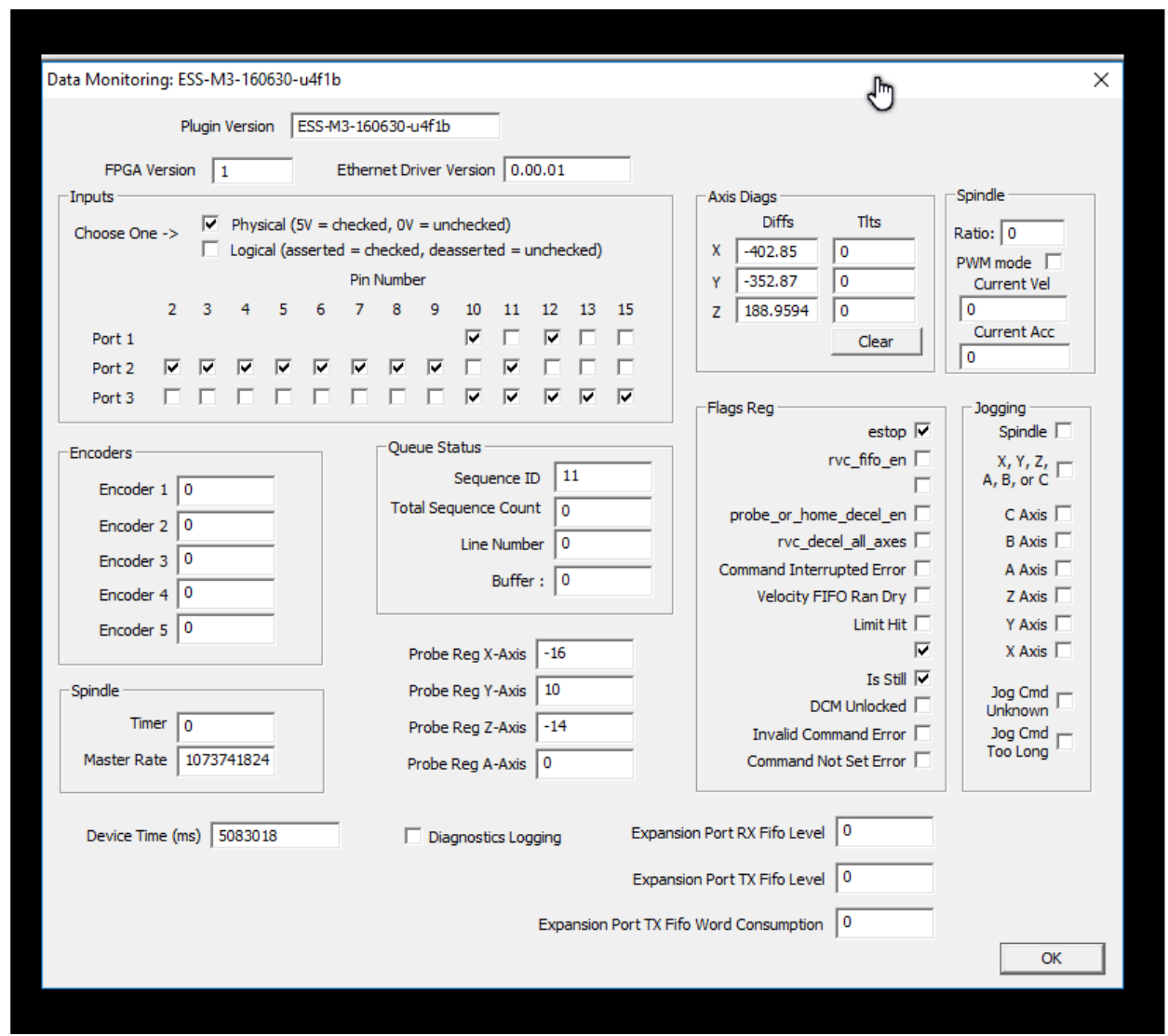

Fig. 5. The Data Monitoring configuration window

The second configuration window, Data Monitoring, is used for "previewing" the exchange of information between the controller and Mach3 (Mach4) - Figure 5.

\section{The mechanical system}

The whole machine tool construction is based on large cross-section thick-walled closed section bars of enhanced-strength steel S355J2 - Figure 6 . The construction was welded by the MAG method using the following welding parameters: current intensity - welding currents, 270-280 A; voltage, $26 \mathrm{~V}$; and $1.2 \mathrm{~mm}$-diameter wire in grade G4Sil. Then, it was subjected to the process of vibration stabilization employed as a technology that substitutes for stress relief annealing. The vibration technology provides dimensional stability similar to the stability obtained during natural ageing [14]. This has allowed a rigid frame structure to be obtained [1].

To obtain high displacement accuracy, high-accuracy profiled rail slideways were used, along which high load-capacity linear ball bearings pre-stressed with 0.03-0.05 Cdynes i.e. $620 \mathrm{~N} / \mathrm{m}$ to move. For each axis, four linear bearings are used, each of a static load capacity of $C O=69160 \mathrm{~N}$. The allowable deviation in absolute dimension among several carriages which are all assigned to a single rail or divided into a pair of rails amounts to $0.015 \mathrm{~mm}$.

Individual supports for the $\mathrm{X}, \mathrm{Y}, \mathrm{Z}$ axes, as well as, optionally, for the A or B axis, are driven by stepper motors with a holding moment of $8.5 \mathrm{Nm}$ through vibration-reducing clearance-free claw couplings mounted axially with a ball screw via a flexible connecting 
link. Linear displacements are effected by a roller screw gear with a spiral lead of $5 \mathrm{~mm}$. The ball screw is executed in accuracy class 5 . The maximum spiral lead error equals 0.018 $\mathrm{mm}$.

Each screw is paired with a prestressed nut (with a prestress torque of 0.07 Cdynes) to remove the reversal backlash.

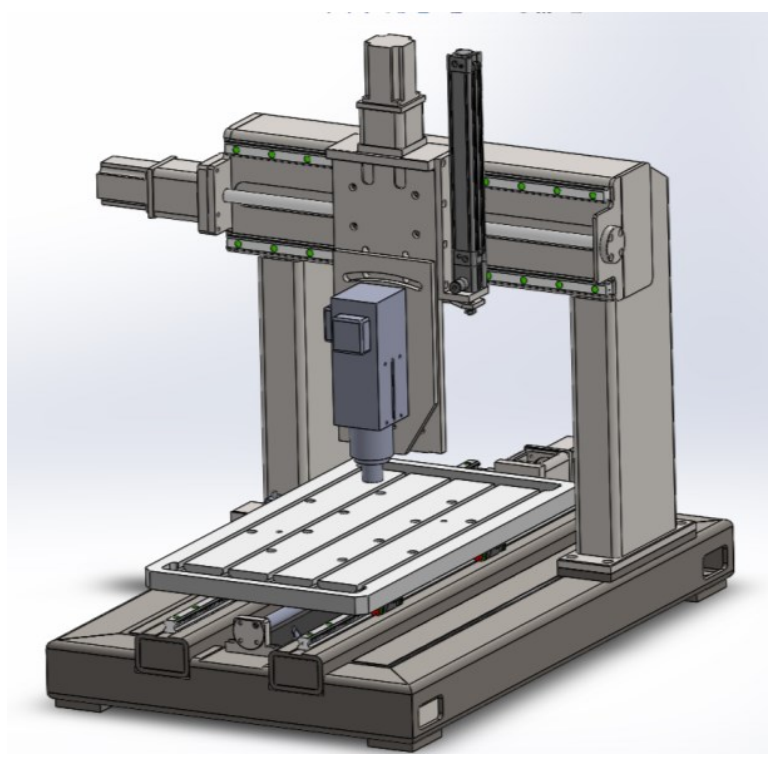

Fig. 6. A three-axis planer mill

The milling machine is optionally furnished with a fourth axis - rotary, numerically controlled A or B, depending on the manner in which it is mounted on the machine tool table - Figure 7. The drive of this axis is also effected by a stepper motor through a toothed belt transmission with a transmission ratio of 1:1.8 and onto a spindle ended with a selfcentring chuck. For machining rolls of a length exceeding the diameter, a tailstock with a dead centre is used for supporting on the other side.

In addition, the milling machine's spindle is capable of being set at an angle within a narrow range of \pm 10 degrees.

A $5.5 \mathrm{~kW}$ electric spindle of a maximum rotational speed of $18000 \mathrm{rpm}$ and with an ER32 tip for fixing tools with a cylindrical grip is used as the main drive of the milling machine. The rotations of the electric spindle are regulated by a Simens Sinamics V20 inverter.

For unloading the spindle frame, a pneumatic servomotor with a brake is employed. The brake activates when there is no pressure and blocks the movement of the servomotor piston rod, thereby holding the spindle support at the current level (the spindle does not fall down).

The working space in individual axes, $x / y / z$, is $450 / 720 / 320 \mathrm{~mm}$, respectively. 


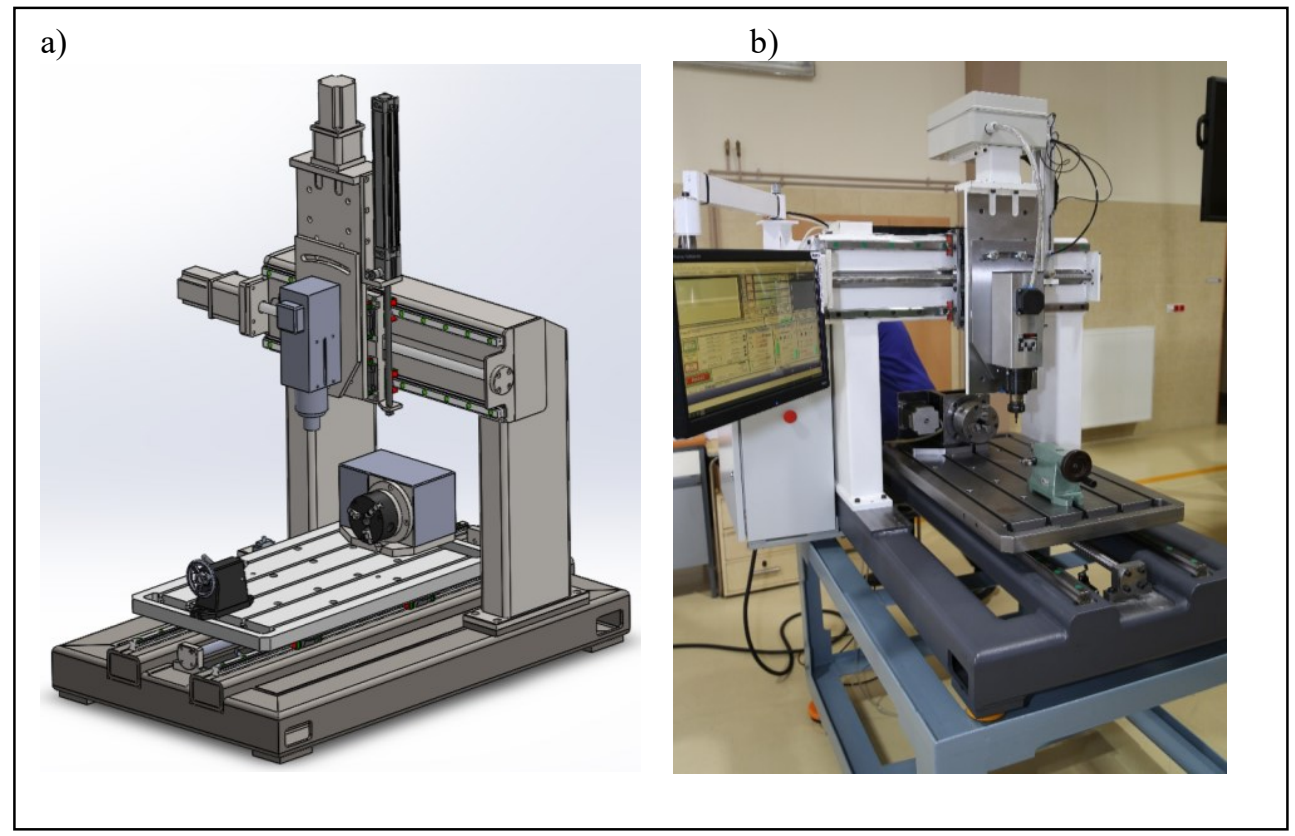

Fig. 7. The milling machine furnished with the forth rotation axis: a) model, b) milling machine

\section{Investigation results}

The basic feature of any machine tool, in addition to the technological capabilities, control and the working space size, is its accuracy and rigidity.

The most important criteria for the assessment of a machine tool's accuracy are: geometric accuracy, positioning accuracy and machining accuracy. The first two criteria apply to the accuracy of machine tool execution, while the third one is a measure for the assessment of the effects of machine tool working. The examination of the geometric accuracy of a machine tool are standardized (PN-ISO 230-1:1998, PN-ISO 230-2:1999, PN-ISO 230-4-1999) and involve the verification of the dimensions, shape and position of the machine tool's components and their relative displacements [15].

The accuracy of a machine tool is influenced by individual stages of production of the machine tool's parts that should be checked (Fig. 8b) and their assembly. After putting the machine tool's assemblies together, the geometric accuracy of individual relative displacements (rectilinearity and perpendicularity) was verified (Fig. 8a). This accuracy was verified using an angle plate in accuracy class IT0, which was appropriately positioned along two mutually perpendicular guides determining the motion of numerically controlled axes and a dial gauge with an accuracy of $0.001 \mathrm{~mm}$. The dial gauge was positioned, depending on the measurement to be taken, e.g. on the table, when measuring the rectilinearity of the $\mathrm{Z}$ axis (Fig. 8a), or on the spindle, when verifying the perpendicularity. 


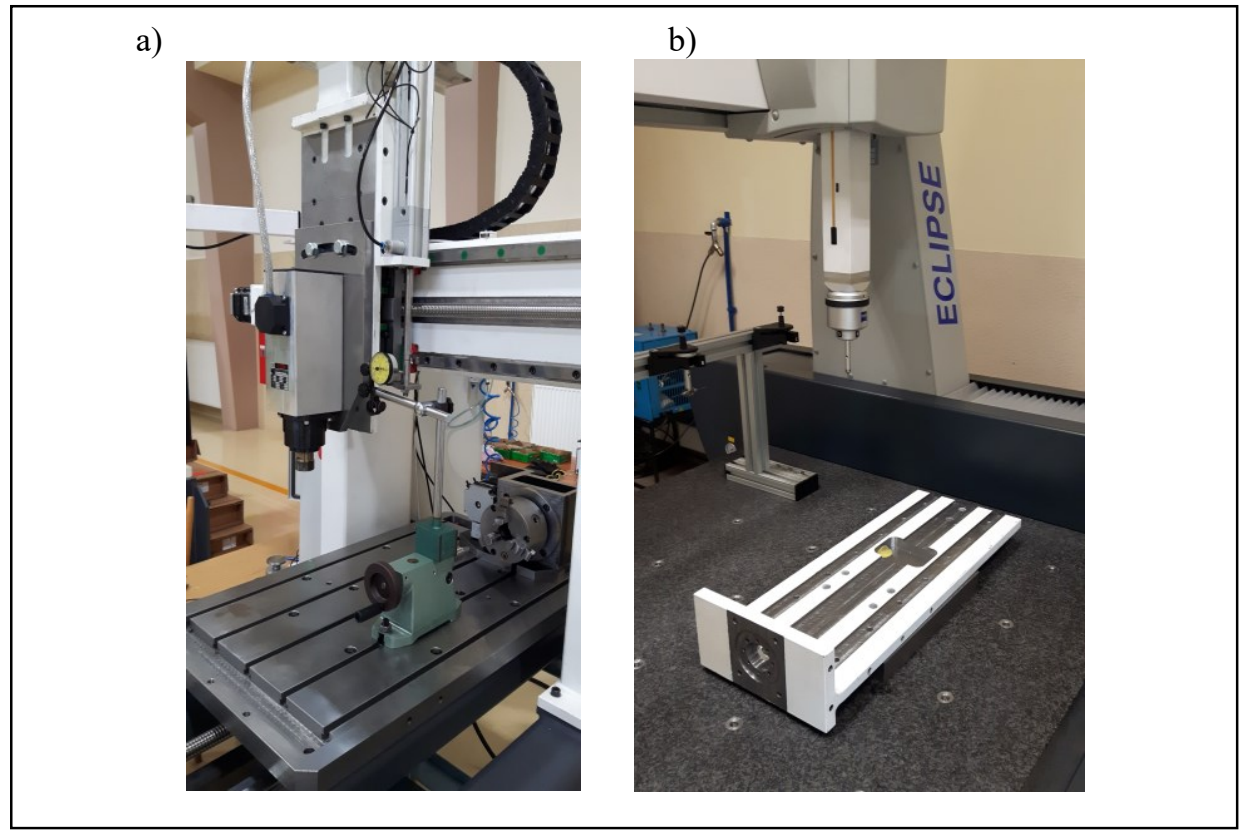

Fig. 8. The verification of accuracy: a) measurement of the rectilinearity of motion along the $Z$ axis, b) measurement of the accuracy of the $\mathrm{Z}$ axis frame

After performing the examination, a motion rectilinearity accuracy of up to $0.01 \mathrm{~mm}$ was obtained in each of the verified axes, while the mutual perpendicularity was up to 0.01 $\mathrm{mm}$ along the angle plate arm lengths $(600 \mathrm{~mm} \times 300 \mathrm{~mm})$.

The machining accuracy, known also as the resultant accuracy of the machine tool, provides the possibility of assessing the accuracy of the entire machining system, including the tool and the influence of all factors occurring in the machining process (forces and vibrations during machining). By the method of verification by machining, the accuracy of objects is assessed by measuring the shape, dimensions and the relative position of the machined surfaces $[16,17]$.

To verify the resultant accuracy, a block with mutually perpendicular walls and a cylinder with a coaxial groove inside it were made on the machine tool.

The measurement of the cylinder roundness was made on a TalyRound 240 device. As shown by Figure 9, the error of roundness of the produced part is $0.01 \mathrm{~mm}$. It can be noticed that this error is due to the reversal error, and the magnitude of this error is small. 


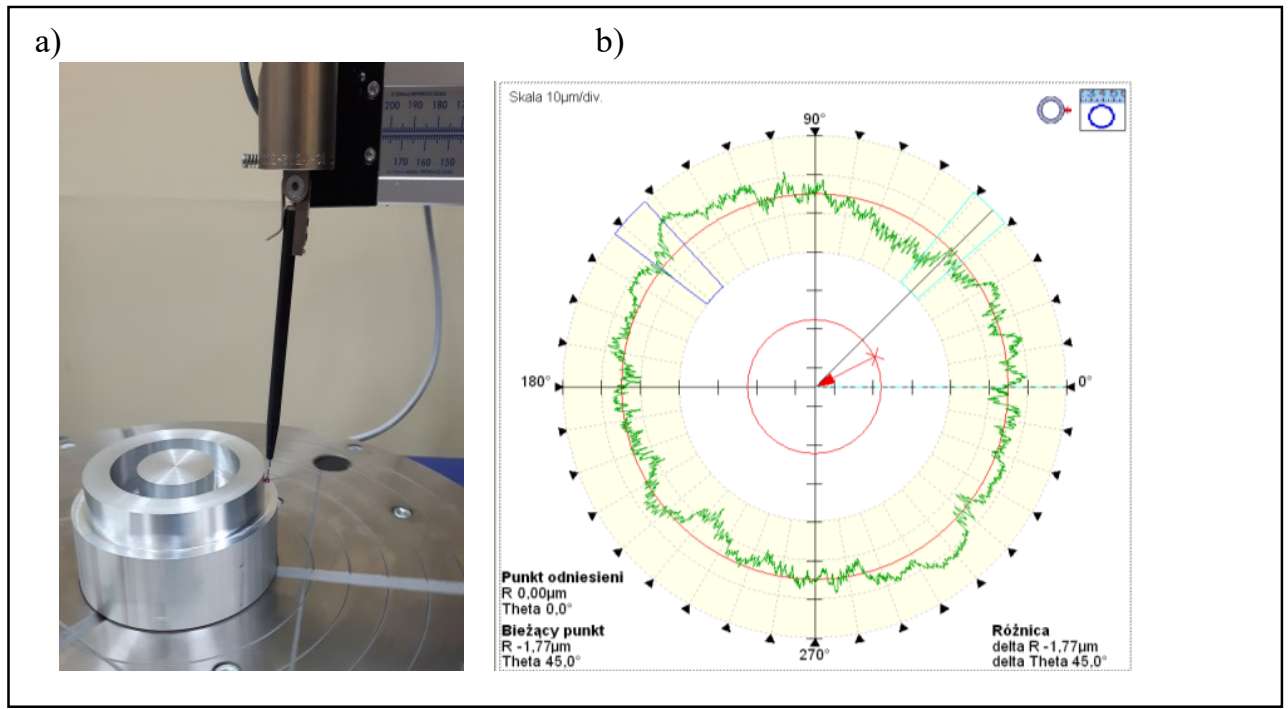

Fig. 9. Verification of accuracy: a) measurement of roundness, b) result of the roundness measurement

The element of the machine tool accuracy examination was a test for the perpendicularity of tool movement across mutually perpendicular guides. A machined block was measured on a Zeiss Eclipse coordinate measuring machine with an ST3 gauging point - Fig. 10.

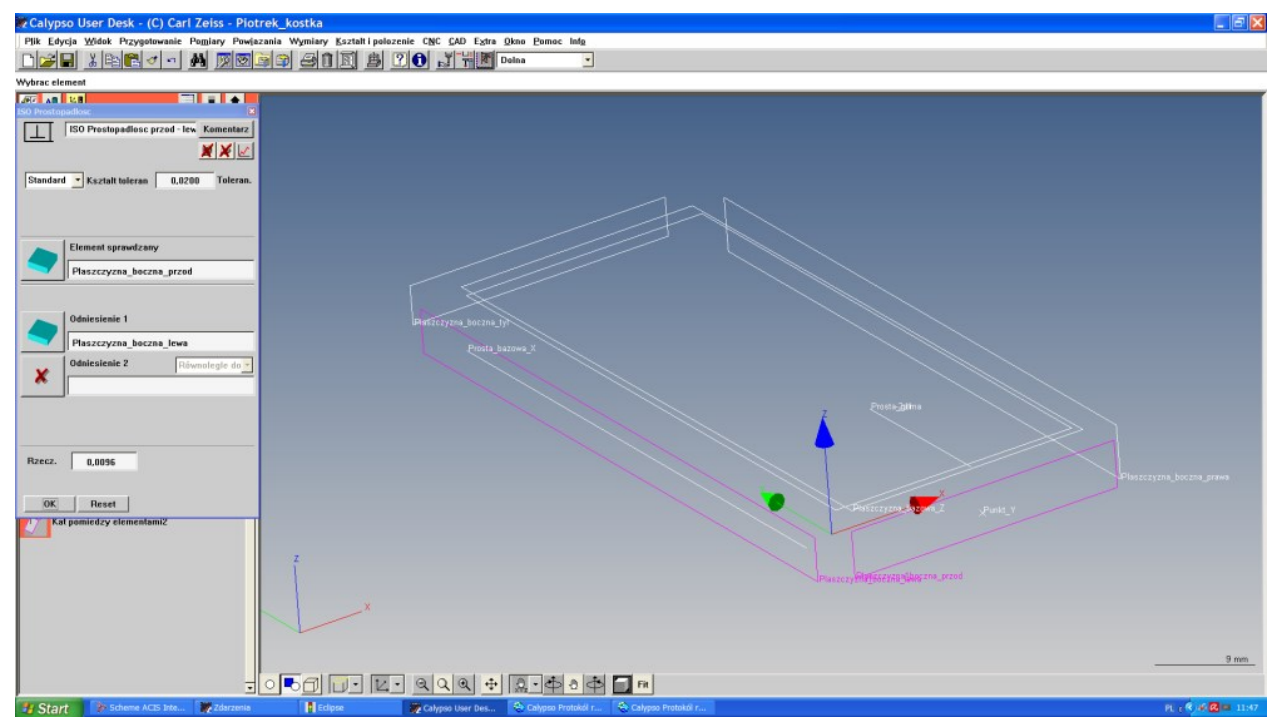

Fig. 10. Verification of the perpendicularity of planes

The measurement results showed small machine tool errors. The measurement of both the roundness and perpendicularity of the guides showed that the observed errors were caused largely by the vibrations of the tool-workpiece system. The measured deviations of machined objects do not exceed the allowable assumed values, therefore the machine tool meets the established conditions for machining accuracy. 


\section{Conclusions}

This is a 4-axis CNC milling machine with sufficiently high rigidity and accuracy.

The machine tool is intended chiefly for machining geometrically complex surfaces by the Step-by-Step method with small-diameter cutters.

The fourth axis of rotation, in the form of a workpiece spindle with a three-jaw selfcentring chuck situated on the milling machine's table can be regarded as an option.

The fourth axis enables the machining of surfaces of revolution and toothing (for example, helical surfaces) by milling.

The employed control system with the Mach3 program and the SmoothStepper controller is very effective. It allows high rotational speeds of motors to be achieved without losing steps.

\section{References}

1. P. Boral, T. Nieszporek, R. Gołębski, The welded CNC machine tool frame, MATEC Web of Conferences 157, $01003 \mathrm{https} / / /$ doi.org/10.1051/matecconf/201815701003 (2018)

2. K.E. Oczoś, Forum obrabiarek skrawających - przykłady nowych rozwiązań prezentowanych na EMO 2007. Cz.I Mechanik 81, nr 12 s. 971-981 (2007). Cz.II Mechanik 82 nr 1, s. 5-15 (2008)

3. http://www.elektroda.pl/rtvforum/topic3137809.html

4. P. Boral, Technological determinants of the teething geometry of worm gears with either a fixed or variable pitch worm, Czestochowa University Press of the Czestochowa University of Technology (2018).

5. T. Nieszporek, P. Boral, Examination of the Cylindrical Worm Profile, MATEC Web of Conferences 94, 07007, https://doi.org/10.1051/matecconf/20179407007 (2017)

6. T. Nieszporek, R. Gołębski, P. Boral, Shaping the Helical Surface by the Hobbing Method, Procedia Engineering 177, pp. 57-63, https://doi.org/10.1016/j.proeng.2017.02.181 (2017)

7. T. Nieszporek, R. Gołębski, L. Soos, Analysis of the wormwheel toothing accuracy, Technical Gazette, 24(4), 993-1000, https://doi.org/10.17559/TV-20160422094400 (2017)

8. R. Gołębski, I. Željko, Analysis of Modification of Spur Gear Profile, Technical Gazette, 25(2), 643-648, https://doi.org/10.17559/TV-20171018100732 (2017)

9. https://atmsolutions.pl/produkt/61/Program_Mach3/15

10. Using Mach3Mill. A user's guide to installation, configuration and operation. (C) 2003/4/5/6 Art Fenerty and John Prentice, http://www.machsupport.com/wpcontent/uploads/2013/02/Mach3Mill_1.84.pdf

11. https://www.akcesoria.cnc.info.pl/242-sterowanie-maszyn-cnc/plyty-glowne-sterownikowcnc/123-plyta-glowna-sterowania-cnc-ssk-mb2

12. https://automationtechnologiesinc.com/wp-content/uploads/downloads/2015/01/EthernetSmoothstepper-Setup-Guide.pdf

13. https://warp9td.com/index.php/documentation

14. I. Smardźić, T. Vuherer, D. Marić, P. Konjatić, Influence of vibrations on residual stresses distribution in welded joints, Technical Gazette, 54(3) 527-530 (2015)

15. J. Honczarenko, Obrabiarki sterowane numerycznie, Numerically controlled machine tools. (WNT, Warsaw, 2008)

16. A. Piotrowski, T. Nieszporek, Coordinate Methods of the Assessment of CNC Machine-Tool Circular Interpolation Accuracy, Advances in Coordinate Metrology, s. 207-221, Bielsko Biała (2010)

17. A. Piotrowski, T. Nieszporek, Poprawa dokładności obróbki z wykorzystaniem wspótrzędnościowej techniki pomiarowej, Enhancing accuracy of the machining using the coordinate metrology. Archiwum Technologii Maszyn i Automatyzacji, s. 99-105, vol. 30, nr 2, (2010) 